\title{
SCIENTIFIC COMMUNICATION \\ Naididae (Annelida, Oligochaeta) associated with
briophytes in Brotas, State of São Paulo, Brazil
}

\author{
Guilherme Rossi Gorni ${ }^{1} \&$ Roberto da Gama Alves ${ }^{2}$
}

\author{
1 Programa de Pós-graduação em Ciências Biológicas, Comportamento e Biologia Animal, Departamento de Zoologia, \\ Instituto de Ciências Biológicas, Universidade Federal de Juiz de Fora. 36036-330 Juiz de Fora, Minas Gerais, Brasil. \\ E-mail: guilhermerossim2@yahoo.com.br; galves@icb.ufj.br
}

\begin{abstract}
Mosses and liverworts can be colonized by various invertebrates, including fresh water oligochaete worms. However, little information is available on the habits and habitats of this oligochaetes in Brazil. Therefore, the present study was undertaken to examine the occurrence of naidids in mosses, as well as to broaden the knowledge about the habitats of these oligochaetes. Sampling of bryophytes adhered to rock substrates in the rapids of the Jacaré Pepira River (municipality of Brotas, São Paulo, Brazil) and to a vertical rock wall of a waterfall near the river revealed 191 Naididae individuals of the species Nais communis Piguet, 1906, Pristinella jenkinae (Stephenson, 1931) and Pristinella menoni (Aiyer, 1929). We believe this to be the first record of naidids associated with mosses in Brazil.

KEY WORDS. Associated fauna, mosses, oligochaete worms, Nais, Pristinella.
\end{abstract}

RESUMO. Naididae (Annelida, Oligochaeta) associadas a briófitas em Brotas, Estado de São Paulo, Brasil. Musgos e hepáticas podem ser colonizados por diversos invertebrados, incluindo os vermes Oligochaeta. Contudo, existe pouca informação na literatura brasielira sobre os hábitos e hábitats destes oligoquetos. Portanto, o presente trabalho foi realizado para examinar a ocorrência de naidídeos em musgos, bem como aumentar o conhecimento dos habitats destes anelídeos. A coleta de briófitas aderidas a substratos rochosos nas corredeiras do Rio Jacaré Pepira (Brotas-SP) e à parede rochosa vertical de uma cachoeira localizada nas proximidades do referido rio revelou 191 indivíduos de três espécies de Naididae: Nais communis Piguet, 1906, Pristinella jenkinae (Stephenson, 1931) e Pristinella menoni (Aiyer, 1929). Acredita-se que este seja o primeiro registro de Naididae vivendo em briófitas no Brasil. PALAVRAS-CHAVE. Fauna associada, musgos, vermes oligoquetos, Nais, Pristinella.

Aquatic bryophytes are an inseparable and important part of lotic ecosystems (VLCKVÁ et al. 2002). These plants can be colonized by a series of invertebrates (Suren 1993), among them several species of Naididae. These Oligochaeta worms, are predominantly free swimmers (Verdonschot et al. 1982), and can therefore exploit a wide range of habitats, including: sediments (STACEY \& Coates 1996, Alves \& Strixino 2000), fine sediments of caves (Wetzel \& TaYlor 2001), macrophytes (NeifF \& Caringnan 1997), sponges (Righi 1984, Corbi et al. 2005) and even the dorsum of Odonata larvae (Corbi et al. 2004). Suren (1993), VlCKVÁ et al. (2002) and Habdija et al. (2004) studied extensively the macrofauna associated with mosses, however they did not give any details on oligocahaetes, reafirming the general lack of information on the association between these animals and other substrates in freshwater environments. The aim of this study was to examine the occurrence of naidids in mosses, as well as to broaden the knowledge about the habitats of these oligochaetes.

Samples were obtained from the municipality of Brotas $\left(22^{\circ} 17^{\prime} 12^{\prime \prime}\right.$ S and $\left.48^{\circ} 07^{\prime} 35^{\prime \prime} W\right)$, in central São Paulo State, Brazil, at an elevation of 661 meters. Moss samples of the genus Fissidens
(Fissidentacea) and Philonotis (Bartramiaceae) were collected in winter and spring of 2003 from rocky substrates of the rapids of the Jacaré Pepira River (MR) and from the rock wall of a nearly waterfall (MW).

The mosses were carefully removed from the rocks using a metal blade and immediately placed in five-liter plastic jugs containing stream water. In the laboratory, they were carefully placed in plastic trays with a small amount of water over a light box, permitting visualization of the associated animals while still alive. These were collected and immediately fixed in 4\% formalin.

The Oligochaeta worms were identified using the taxonomic keys of BrinkHurst \& Jamieson (1971), Righi (1984) and BRINKHURST \& MARCHESE (1989). The species identified were preserved in labeled glass jars containing 70\% alcohol and are deposited in annelid collection of the Department of Zoology at the Federal University of Juiz de Fora (UFJF).

A total of 191 individuals associated with the mosses were identified, all of them belonging to 3 species of the Naididae family: Nais communis Piguet, 1906, Pristinella jenkinae (Stephenson, 1931) and Pristinella menoni (Aiyer, 1929). Among

Revista Brasileira de Zoologia 24 (2): 518-519, junho 2007 
the species identified, $P$. jenkinae was dominant, being responsible for $96.8 \%$ of all individuals, and was sampled in both habitats (Tab. I). The numerical dominance of this species indicates its ability to live in both inundated environments (mosses of streambeds) and habitats with little water (mosses living on rock walls). We believe this work to be the first register of naidids associated with mosses in Brazil.

Table I. Number of individuals of Naididae associated with bryophytes of the Fissidens (MR: mosses associated with river rapids) and Philonotis (MW: mosses associated with rocks of the waterfall) genera in the winter and spring of 2003.

\begin{tabular}{|c|c|c|c|c|c|}
\hline \multirow{2}{*}{ Taxa } & \multicolumn{2}{|c|}{ Winter, 2003} & \multicolumn{2}{|c|}{ Spring, 2003} & \multirow{2}{*}{ Total } \\
\hline & MR & MW & MR & MW & \\
\hline \multicolumn{6}{|l|}{ Naididae } \\
\hline Nais communis & 1 & 4 & & & 5 \\
\hline Pristinella jenkinae & & 25 & 72 & 88 & 185 \\
\hline Pristinella menoni & & 1 & & & 1 \\
\hline Number of individuals & 1 & 30 & 72 & 88 & 191 \\
\hline Number of taxa & 1 & 3 & 1 & 1 & 3 \\
\hline
\end{tabular}

The presence of naidid species in this type of substrate may be related to factors that facilitate the development of such fauna, such as reduced current speed and the presence of shelter (VlckVÁ eT al. 2002). For example Habdija et al. (2004) found a direct relationship between river current speed and the density of macro invertebrates associated with mosses. Another factor that is closely related to the abundance and diversity of freshwater invertebrates is the biomass of bryophytes, together with the periphyton and the amount of debris associated with them (EgGlishaW 1969, Suren 1993). For instance, Linhart et al. (2002) found that the presence of mosses increased the spatial diversity of the habitat, as well as the density of macro invertebrates that contributed substantially to stream metabolism.

Therefore considering that the occupation of freshwater habitats can be related to evolutionary advantages - such as feeding opportunities, increased mobility, and protection against disturbances and predation risk (TOKESH 1993) - more information on this subject is needed, especially regarding the Oligochaeta fauna.

\section{ACKNOWLEDGMENTS}

To Douglas F. Peiró, Amanda P. Ucci, Andréa P.L. Ponzo and the State of São Paulo Research Foundation (FAPESP) BIOTA/Program for their support.

\section{REFERENCES}

Alves, R.G. \& G. Strixino. 2000. Distribuição espacial de Oligochaeta do sedimento de uma lagoa marginal do rio MogiGuaçu- SP. Iheringia, Série Zoologia 88: 173-180.
BrinkHURST, R.O. \& B.G.M. JAMIESON. 1971. Aquatic Oligochaeta of the world. University of Toronto Press, 860p.

BrinkHurst, R.O. \& M.R. MARChESE. 1989. Guia para la indentificación de Oligoquetos aquáticos continentales de Sud y Centroamérica. Santa Fé, Asociación de Ciencias Naturales del Litoral, 207p.

Corbi, J.J.; M.A. Janeso; S. Trivinho-Strixino \& E.N. Fragoso. 2004. Occurence of Oligochaeta living on larvae of Odonata from Ipeúna (São Paulo State, Brazil). Biota Neotropica 4(2): 1-3.

Corbi, J.J.; S. Trivinho-Strixino \& R.G. Alves. 2005. Records of oligochaetes in freshwater sponges, on bryozoarians and on colonial hydrozoans from Brazil. Brazilian Journal of Biology 65 (1): 187-188.

Egglishaw, H.J. 1969. The Distribution of Benthic Invertebrates on Substrata in Fast-Flowing Streams. Journal of Animal Ecology 38 (1): 19-33.

Habdija I.; B. Primc Habdija; R. Matonickin; M. Kuciníc; I. Radanovíc; M. Miliša \& Z. Mihaljevíc. 2004. Current velocity and food supply as factors affecting the composition of macroinvertebrates in bryophyte habitats in karst running water. Biologia, Bratislava 59 (5): 577-593.

Linhart J.; S. VlCKVÁ \& V. Uvíra. 2002. Bryophytes as a special mesohabitat for meiofauna in a rip-rapped channel. River Research and Applications 18 (4): 321-330.

Neiff, A.P. \& R. Caringnan. 1997. Macroinvertebrates on Eichhornia crassipes in two lakes of the Paraná River foodplain. Hydrobiologia 345: 185-196.

Righi, G. 1984. Manual de identificação de invertebrados límnicos do Brasil. Brasília, CNPq, Coordenação Editorial, 48p.

StaCey, D.F. \& K.A. CoATes. 1996. Oligochaetes (Naididae, Tubificidae, Opistocystidae, Enchytraeidae, Sparganophilidae and Alluroididae) of Guyana. Hydrobiologia, Brussels, 334: 1729.

SuREN, A. 1993. Bryophytes and associated invertebrates in firstorder alpine streams of Arthur's Pass, New Zealand. New Zealand Journal of Marine and Freshwater Research 27: 479-494.

TOKeSHI, M. 1993. On evolution of commensalism in the Chironomidae. Freshwater Biology 29: 481-489.

Verdonschot, P.F.M.; M. SMIEs \& A.B.J. SePERs. 1982. The distribution of aquatic oligochaetes in brackish inland waters in the SW Netherlands. Hydrobiologia 89: 29-38.

VlckVÁ, S.; J. Linhart \& V. Uvíra. 2002. Permanent and temporary meiofauna of an aquatic moss Fontinalis antipyretica Hedw. Acta Universitatis Palackianae Olomucensis 39-40: 131-140.

Wetzel, M.J. \& S.J. TAYLOR. 2001. First records of freshwater oligochaetes (Annelida, Clitellata) from caves in Illinois and Missouri, USA. Journal of Cave and Karst Studies 63 (3): 99-104.

Received in 28.VII.2006; accepted in 09.V.2007.

Revista Brasileira de Zoologia 24 (2): 518-519, junho 2007 